\title{
The Role of Information and Electronic Transactions Law in Controlling Teacher Activities in the Digital World at SDN Cimanggis 03 Bogor
}

\author{
ASWIN FITRIANSYAH, ADHI SUSANO, TRIA HADI KUSMANTO
}

\author{
Universitas Indraprasta PGRI Jakarta \\ Email : aswin.fitriansyah@gmail.com
}

Received 29 June 2021 | Revised 30 June 2021 | Accepted 3 July 2021

\begin{abstract}
Education, business, industry and other fields use social media in their work. Utilization of technology in accordance with its needs is facilitated with social media in the industrial era 5.0. All sectors use online media due to the covid-19 pandemic. Information and communication in social media there are restrictions to be done openly or not allowed to be done. The Information and Electronic Transactions Act (ITE Law) regulates the provisions of communication. Regulatory ratification to protect the public from cybercrime in cyberspace. Defamation, blasphemy and online threats are contained in the article of the law. Principals, teachers and employees are given counseling on the role of the law when interacting and communicating on social media in community service activities conducted.
\end{abstract}

Keywords: ITE Law, communication, education, social media, digital world

\section{INTRODUCTION}

Daily print media such as newspapers, magazines, and other print media are almost obsessible with the presence of social media in cyberspace. Popular newspapers such as The Washington Post and the print edition of the Wall Street Journal are now distributed for free in most downtowns in the United States. In Indonesia, Sinar Harapan newspaper closed on January 1, 2016, following daily, Football, National Journal, and editorial magazines such as Prospek, and Fortune (Kusuma, 2016). In his writing entitled the position of print media in the midst of the development of online media in Indonesia, the phenomenon of online media which is predicted to replace print media continues to increase in Indonesia. In addition, the impact of online media on print media is felt, the facts in the field today that the authors find that it is very rare for people to buy newspapers to read news, who buy only the elderly, while young people prefer social media, because internet facilities on smart cellphones make it easier for people to access information, in the journal the impact of online media on the development of conventional media (Nurkinan, 2017). Various information that a person or group wants can be done and obtained in a short time with the use of communication media such as smartphones. From various sectors, online-based social media has accompanied education, business, industry and other fields using social media in their work. 
Someone accessing online media in the cyber world can be done anytime and anywhere. Using social media in various sectors is carried out in all conditions, especially conditions during the COVID-19 pandemic. Utilization of technology according to their needs is facilitated by social media in the industrial era 5.0. Information, business, education and all of them can change function significantly in social media that contains various data sources. It is very easy to disseminate information or obtain information, making the awareness of something that is informed decrease because there is a lot of personal information being disseminated and even very confidential information can be obtained through digital social media. Some social media users do not yet know or realize that Information and communication in social media there are restrictions to be done openly or not allowed to do. In connection with the provision, a regulation is formed in the Information and Electronic Transactions Act (ITE Law) governing communication provisions.

Legal counseling of information and electronic transactions has been conducted by (Purwaningsih et al., 2019) where the activity seeks the problem of partners who are addressed is how efforts to socialize regulation and education are carried out on students and teachers of SDN 05 Cempaka Baru in order to improve the legal knowledge of information and electronic transactions. This counseling activity was conducted with lectures and questions and answers with the provision of pre-test and post test, which was held in collaboration with SDN 05 Cempaka Baru, Kemayoran Central Jakarta. Then the result of the activity is the implementation of activities followed by teachers and students of grades $\mathrm{V}$ and VI and the results of counseling show a significant increase in legal knowledge of information and electronic transactions.

In addition, the socialization of the ITE Law in preparing Cyber Media Vocational School Students to Enter the Campus Environment has been carried out by (Herdiana et al., 2019) This activity is motivated by the many young people who do not understand how to use social media properly and correctly, therefore socialization is needed about the ethics of using the internet, especially social media among school-age children. Based on these problems, counseling on the ITE Law and Preparation for Entering the Campus Environment was carried out at the Cyber Media Vocational School in Jakarta. This activity aims to provide an understanding to Cyber Media Vocational High School students about the importance of ethics in using internet and social media. This activity also aims to provide an overview of the education system at the university in preparation for entering the campus environment. This activity was carried out using the extension method in the form of lectures accompanied by interactive discussions between participants and resource persons. Based on the evaluation after the socialization of the ITE Law and preparation for entering the campus environment, the results showed that there was a very good increase in knowledge and understanding based on the results of the posttest conducted after the activities to students of Cyber Media Vocational School.

Education in this case, namely teaching and learning activities must continue to be carried out, but considering that it is currently still in a COVID-19 pandemic condition, teaching and learning activities are generally still carried out online or online. Teachers and employees must be equipped with knowledge of information regulations so that when communicating and interacting between teachers and students and guardians of students can run smoothly and well by looking at the limitations contained in the ITE Law, the Information and Electronic Transaction Law, where during the covid 19 pandemic, schools are in a state of emergency. daily social media online with various devices and applications used in learning and teaching methods. The law contains provisions regarding the spread of false information 
or hoaxes, defamation uploaded on various social media which then hurts and hate speech causes communication violations that often occur in social media.

In response to the prevailing regulations, improving the professionalism of work and smooth teaching and learning activities online during the covid-19 pandemic. Principals, teachers and employees are given counseling on the role of information law and electronic telecommunications when interacting and communicating on social media conducted in community service activities at SD Negeri Cimanggis 03 Bojonggede - Bogor.

\section{METHODS OF COMMUNITY SERVICE}

\subsection{Partner Selection}

The need for teachers in providing information and in communicating in the digital world must be controlled in a manner that pays attention to the provisions in activities carried out such as the delivery of materials to students and or providing information to parents related to academics at SD Negeri Cimanggis 03 in addressing the role of the ITE Law in controlling teacher activities in the digital world.

\subsection{Procedures and Stages of Implementation}

The procedures and stages of implementation that the community service team arranges are as follows:

\section{Live Observation}

According to (Widoyoko, 2014), observation is "systematic observation and recording of the elements that appear in a phenomenon on the object of research". According to (Sugiyono, 2014) "observation is a complex process, a process composed of various biological and psychological processes". According to (Riyanto, 2010), "observation is a method of data collection that uses direct or indirect observations.

Direct observation, namely the community service team directly visits partner locations to obtain data. This the team did before the activity took place. Observations are useful for knowing the condition of how educators, namely teachers at the school, know the role of the ITE Law in interacting on social media. Observation is very important to realize the success of the community service activity itself.

\section{Socialization and Counseling}

The team of service conducts socialization and counseling on social media in the digital world as well as the role of the ITE Law in controlling teacher activities in the digital world. The activity was conducted for two days where in each meeting held for 3 hours through video conference.

\section{Evaluation and Monitoring}

Evaluation and monitoring is carried out by assigning teachers to check what information has been shared through social media with any application, as well as information that has been obtained by related teachers in the field of education.

\section{Materials and tools}

Materials and tools

Some of the methods used in this activity are socialization methods in the form of counseling delivered by lecturers as Community Service Team to Teachers of SDN Cimanggis 03 and 
accompanied by discussions that present materials on the utilization of information technology media, especially internet utilization in accordance with the provisions of the Information \& Electronic Transactions Act (ITE) and the role of ITE in controlling teacher activities in the digital world. This PKM activity was held at SDN Cimanggis 03 which is located at Jalan Raya Tonjong Desa Cimanggis, Bojonggede Subdistrict, Bogor Regency. The implementation of community service activities lasts for two days.

The method used in the implementation of this community service uses the lecture method in the form of providing material to teachers and employees. In addition, the service team also uses a discussion method in the form of questions and answers from teachers and employees with resource persons. This discussion is carried out so that the material presented is easier for participants to understand by discussing certain cases related to the material presented. In the discussion session, the participants seemed very enthusiastic about asking questions and expressing their respective opinions. To find out the extent to which the material presented was absorbed by the participants, the service lecturer team carried out tasks related to community service materials.

\section{RESULTS AND DISCUSSION}

The event was held at SDN Cimanggis 03 Bojonggede Bogor, attended by teachers and employees, a total of 23 participants. This community service activity begins with the delivery of material related to the types of actions prohibited in the use of information technology, especially related to content originating from the internet.

Material related to community service activities is further violations and crimes in the digital world (Cyber Crime). In the ITE Law has anticipated in such a way the adverse influence of the utilization of information technology. The ITE Law has established which acts include criminal acts in the field of ITE and has determined the nature of evil and assault against various legal interests in the form of certain criminal formulations (Chazawi, 2015).

Information technology plays an important role, both now and in the future. Information technology is believed to bring great benefits and interests to countries in the world (Raharjo, 2002).

Contained in Article 1 of Law No. 19 of 2016 concerning Amendments to Law No. 11 of 2008 concerning Information and Electronic Transactions, it is stated that electronic information is as one or a set of electronic data, including but not limited to writing, sound, images, maps, designs, photographs, electronic data interchange (EDI), electronic mail , telegram, telex, telecopy or the like, letters, signs, numbers, access codes, symbols, or perforations that have been processed that have meaning or can be understood by people who are able to understand them (Indonesia, 2016).

According to (Chazawi, 2015) "The ITE Law is not a special criminal law, because this Law does not merely contain criminal law, but contains about the regulation on the management of information and electronic transactions at the national level, with the aim of developing information technology can be done optimally, evenly, and spread to all levels of society".

The ITE Law has determined which acts are criminal acts in the ITE field and has determined the nature of evil and attacks against various legal interests in the form of certain criminal offenses. 
If observed, the ITE Law has regulated at least 20 (twenty) types of acts that should not be done in connection with the use of ITE media stipulated in articles 27 to 35 . If classified according to his actions can be categorized into 4 (four) deeds, namely:

1. Data and computer system-related breaches. Crimes that fall into this category are:

a. Illegal Access is the crime of entering or infiltrating someone else's computer network system. This crime is stipulated in section 30.

b. Illegal Data Acquisition. The crime of entering a computer network system is intended as a spy or accessing information illegally.

c. Illegal Interception (Interception) The crime of intercepting communications or exchange of data uploaded to web-based external storage media.

d. Data Crime Interventions aimed at deleting or hiding, altering, corrupting, or stealing data.

e. Malicious System Interventions aimed at removing or hiding, altering, tampering with, or stealing systems.

2. Data and computer system-related breaches. Crimes that fall into this category are:

a. Pornography. The act of distributing and or transmitting and or making accessible Electronic Information and or Electronic Documents that have content that violates decency.

b. Online Gambling. The act of distributing and or transmitting and or making accessible Electronic Information and or Electronic Documents that have gambling content.

c. Cyber Bullying. The act of distributing and or transmitting and or making accessible Electronic Information and or Electronic Documents that have a charge of contempt and or defamation.

d. Hoax news. Acts intentionally and without the right to spread false and misleading news that results in consumer losses in Electronic Transactions.

e. Hate Speech. Acts intentionally and without the right to disseminate information intended to incite hatred or hostility of certain individuals and/or community groups based on ethnicity, religion, race, and inter-group (SARA).

f. Content Containing Threats. Intentional and without right to transmit Electronic Information and/or Electronic Documents containing threats of violence or scaremongering directed in private.

3. Computer-related violations. Crimes that belong to this category are:

a. Deceit. Fraud crimes in cyberspace using false identities.

b. Data Falsification. Acts intentionally and without right or against the law to manipulate, create, alter, omission, destruction of Electronic Information and or Electronic Documents for the purpose that such Electronic Information and or Electronic Documents are considered as authentic data.

c. Identity theft. Acts of theft and use of the identity of others.

4. Copyright and brand-related infringement. Crimes belonging to this category are the act of illegal reproduction of Creation and/or Related Rights products and the distribution of goods multiplied widely for economic gain.

The PKM team provided material files for the ITE Law and explained with slides one by one accompanied by examples of several cases that had happened to several people in the country. Some of the ensnared cases include defamation, insults on social media, hate speech, providing false information on social media and many more cases that intentionally or unintentionally occur in the digital world. During this pandemic all information media is based online, especially in the Education sector, where social media becomes a very reliable 
media today. We should be careful in providing information or materials because everything is regulated in the ITE Law.

Mitra PKM is very enthusiastic to participate in the activities. Many ask questions about chapters they must understand because they as educators need restrictions on giving assignments and information to their students. Some Teachers and Employees propose for additional time because of the importance of information for good in communication through social media. The implementation of community service activities went smoothly and received support from the school. The existence of this community service activity makes the teachers and employees of SDN Cimanggis 03 add insight and be vigilant in communicating on social media, especially in the field of education. ITE Law Becomes the basis of all of us in social media, it is very dangerous if we do not understand because it will be exposed article by article. Like housewives who often disseminate information without seeing the rules contained in the Law. Through socialization and counseling activities about the ITE Law, Teachers and Employees are very helpful even during the covid-19 pandemic is currently conducted through video conferences.

The community service team measured the understanding of information on the ITE Law when the material had not been given and after the material was given. Data is specified in terms of frequency. Table 1 is data on the frequency of understanding the ITE Law before and after receiving the basic materials.

Table 1. Understanding the ITE Law

\begin{tabular}{|c|c|c|}
\hline $\begin{array}{c}\text { Answer } \\
\text { Respondents }\end{array}$ & $\begin{array}{c}\text { Frequency } \\
\text { Before Basic Materials }\end{array}$ & $\begin{array}{c}\text { Frequency } \\
\text { After Basic Materials }\end{array}$ \\
\hline 1 & 9 & 1 \\
\hline 2 & 6 & 2 \\
\hline 3 & 4 & 5 \\
\hline 4 & 3 & 8 \\
\hline 5 & 1 & 7 \\
\hline Total & 23 & 23 \\
\hline
\end{tabular}

Understanding of the ITE Law felt by the participants of counseling can be explained as follows. There are as many as 7 people who have understood very well, as many as 8 people already understand, and as many as 5 people already understand enough. Meanwhile, as many as 3 people still do not understand the ITE Law. In addition, data is also collected based on the results of the benefits of understanding the ITE Law. The data is displayed in table 2.

Table 2. Advantages of ITE Law

\begin{tabular}{|c|c|c|}
\hline $\begin{array}{c}\text { Answer } \\
\text { Respondents }\end{array}$ & $\begin{array}{c}\text { Frequency } \\
\text { Before Materials }\end{array}$ & $\begin{array}{c}\text { Frequency } \\
\text { After Materials }\end{array}$ \\
\hline 1 & 10 & 1 \\
\hline 2 & 5 & 2 \\
\hline 3 & 3 & 4 \\
\hline 4 & 3 & 9 \\
\hline 5 & 2 & 7 \\
\hline Total & 23 & 23 \\
\hline
\end{tabular}

It can be seen in table 2 that respondents who have participated in the activities and provided the results of the counseling as mentioned above, it can be understood that there are already 7 people who are very familiar with the benefits of using the ITE Law. As many 
as 9 people already understand, and as many as 4 people already understand enough about the use of the ITE Law. It's just that there are still as many as 3 people who do not understand the benefits of using the ITE Law.

\section{CONCLUSIONS}

Counseling related to the role of the ITE Law needs to be done not only once, but it needs to be continuously built and improved periodically in line with the dynamics of legal development and the needs of the community, in this case teachers and employees. Socialization of regulation and education is able to increase knowledge and level of legal awareness, especially in the activities of the Role of Information law and Electronic Transactions in Controlling Teacher Activities in the Digital World at SDN Cimanggis 03 Bogor. Socialization and counseling are needed in various schools, especially during the covid 19 pandemic all teachers and employees using online learning both information and communication must comply with the ITE Law so that as educators can be wise in using social media to interact and communicate.

\section{REFERENCES}

Chazawi, A. (2015). Tindak Pidana Informasi \& Transaksi Elektronik Penyerangan Terhadap Kepentingan Hukum Pemanfaatan Teknologi Informasi Dan Transaksi Elektronik (Edisi Revisi). Media Nusa Creative.

Herdiana, D., Hadi, A., \& Arifai, M. K. (2019). Sosialisasi Undang-Undang ITE Dalam Mempersiapkan Siswa SMK Cyber Media Memasuki Lingkungan Kampus. Jurnal Loyalitas Sosial: Journal of Community Service in Humanities and Social Sciences, 1(2), 92. https://doi.org/10.32493/jls.v1i2.p92-103

Indonesia, P. R. (2016). Undang-Undang Republik Indonesia No. 19 Tahun 2016 tentang Perubahan Undang- Undang No. 11 Tahun 2008 tentang Informasi dan Transaksi

Elektronik. https://web.kominfo.go.id/\%0Asites/default/files/users/4761/UU 1\%0A9 Tahun 2016.pdf

Kusuma, S. (2016). Posisi Media Cetak di Tengah Perkembangan Media Online di Indonesia Satria Kusuma. InterAct Program Studi IImu Komunikasi FIABIKOM Unika Atmajaya Jakarta, 5(1), 56-71.

Nurkinan. (2017). Dampak Media Online Terhadap Perkembangan Media Konvensional. Jurnal Politikom Indonesiana, 2(2), 33-34.

Purwaningsih, E., Rahmanto, D., \& Ariyanti, E. R. N. (2019). Penyuluhan Hukum Informasi Dan Transaksi Elektronik Bagi Para Guru Dan Siswa Sdn 05 Cempaka Baru Kemayoran Jakarta Pusat. Jurnal Pengabdian Masyarakat Universitas Merdeka Malang, 3(0), 1-4. https://doi.org/10.26905/abdimas.v3i0.2645

Raharjo, A. (2002). Cybercrime, Pemahaman dan Upaya Pencegahan Kejahatan Reka Elkomika-47 
Berteknologi. Citra Aditya Bakti.

Riyanto, Y. (2010). Metodologi Penelitian Pendidikan. SIC.

Sugiyono. (2014). Metode Penelitian Pendidikan Pendekatan Kuantitatif, Kualitatif, dan R\&D. Alfabeta.

Widoyoko, E. P. (2014). Evaluasi Program Pembelajaran. Pustaka Pelajar. 